Atherogenesis may also be stimulated via the connexion which has been demonstrated between hyperglycaemia, hyperinsulinaemia, and hypertriglyceridaemia (Abrams et al., 1969).

Further studies on the atherogenic properties of insulin would appear to be warranted in the light of these results.

We thank Professor Sir John H. Biggart and Mr. D. W. Neill for their help and advice. We are also grateful to Dr. J. D. Merrett for his statistical advice.

Requests for reprints should be sent to Dr. J. M. Sloan.

\section{REFERENCES}

Abrams, M. E., Jarrett, R. J., Keen, H., Boyns, D. R., and Crossley, J. N. (1969). British Medical fournal, 1, 599.

Boyns, D. R., Crossley, J. N., Abrams, M. E., Jarrett, R. J., and Keen, H. (1969). British Medical fournal, 1, 595.

Buchanan, K. D., and McKiddie, M. T. (1967). Diabetologia, 3, 460.

Cochran, W. G., and Cox, G. M. (1957). In Experimental Design, 2nd edn. London, Chapman and Hall.
Danowski, T. S. (1970). Postgraduate Medical fournal, 46, 125.

Datey, K. K., and Nanda, N. C. (1967). New England fournal of Medicine, 276, 262 .

Davidson, P. C., Shane, S. R., and Albrink, M. J. (1966). Circulation, 33, suppl. 3, p.7.

Devlin, J. G., and Stephenson, N. (1968). Metabolism, 17, 999.

Edwards, K. D. G., and Whyte, H. M. (1962). Clinical Science, 22, 347.

Fitzgerald, M. G., and Keen, H. (1964). Lancet, 1, 1325.

Hales, C. N., and Randle, P. J. (1963). Lancet, 1, 200.

Hoffman, W. S. (1937). Journal of Biological Chemistry, 120, 51.

Keen, H., et al. (1965). Lancet, 2, 505.

Kingsbury, K. J. (1968). Postgraduate Medical fournal, 44, 944.

Kuo, P. T. (1968). Annals of Internal Medicine, 68, 449.

Ostrander, L. D., Neff, B. J., Block, W. D., Francis, T., and Epstein, F. H. (1967). Annals of Internal Medicine, 67, 34.

Peters, N., and Hales, C. N. (1965). Lancet, 1, 1144.

Robertson, A. L. (1968). Progress in Biochemical Pharmacology, 4, 305.

Rose, G. A. (1962). Bulletin of the World Health Organization, 27, 645

Seltzer, H. S., Allen, E. W., Herron, A. L., and Brennan, M. T. (1967) fournal of Clinical Investigation, 46, 323.

Stout, R. W. (1968). Lancet, 2, 702.

Stout, R. W., and Vallence-Owen, J. (1969). Lancet, 1. 1078.

Tzagournis, M., Seidensticker, J. F., and Hamwi, G. J. (1967). Annals of Internal Medicine, 67, 42.

Welborn, T. A., Breckenridge, A., Dollery, C. T., Rubenstein, A. H., and Fraser, T. R. (1966). Lancet, 1, 1336.

\title{
Urinary Tract Dilatation and Oral Contraceptives
}

\author{
P. B. GUYER, ${ }^{*}$ M.R.C.P., F.F.R. ; D. DELANY, $†$ D.M.R.D.
}

British Medical fournal, 1970, 4, 588-590

\begin{abstract}
Ummary: Six nulliparous patients were found to have overdistensiblity : of the upper urinary tract on excretion urography. Of these five had had persistent or recurrent urinary infections. All had been or were receiving oral contraceptives. Though overdistensibility associated with contraceptive therapy is unlikely to be life-threatening, it may be associated with increased patient morbidity.
\end{abstract}

\section{Introduction}

Six women who were referred for excretion urography showed overdistensibility of part of the upper urinary tract, a finding normally seen after pregnancy. Nevertheless, none of these patients had been pregnant, though all had at some time received cyclical oral hormone therapy for menstrual irregularity or contraception. This finding occurred incidentally during an investigation of overdistensibility of the female upper urinary tract.

\section{Clinical and Laboratory Features}

Five patients were referred for urography on account of persistent or recurrent urinary tract infection (Table I). The sixth was referred for investigation of loin pain. Before the injection they were all closely questioned about their symptoms, with particular reference to frequency, dysuria, and haematuria. We accepted a diagnosis of infection if any two of these three symptoms were present. The patients were also questioned about hormone therapy. Because many of them were referred by general practitioners, the excretion urograms were often performed three to four weeks after the acute symptoms had occurred. Most patients had at least one examination of a midstream specimen of urine, but the results of this correlated poorly with the clinical symptoms, since the midstream specimen showed bacteriological proof in only two

* Consultant Radiologist.

† Senior Registrar in Diagnostic Radiology.

$\boldsymbol{X}$-ray Department, Southampton General Hospital, Southampton. of the five patients in whom infection had been clinically diagnosed.

\section{Method}

All excretion urograms were performed the same way. A minimum of $50 \mathrm{ml}$. of Conray 420 was injected, and a fiveminute film of the renal areas was taken. Abdominal compression was then applied with the Cuthbert Andrews apparatus, inflated to a minimum pressure of $200 \mathrm{~mm}$. $\mathrm{Hg}$, and a 10minute film of the kidneys was taken. Provided these two films were satisfactory, full-length films of the urinary tract were taken on release of the abdominal compression and after micturition. Because of the possibility that the overdistensibility might be associated with ureteric reflux three of the six patients underwent micturating cystourethrography; in no instance did reflux occur.

What we consider to be normal compression effects during

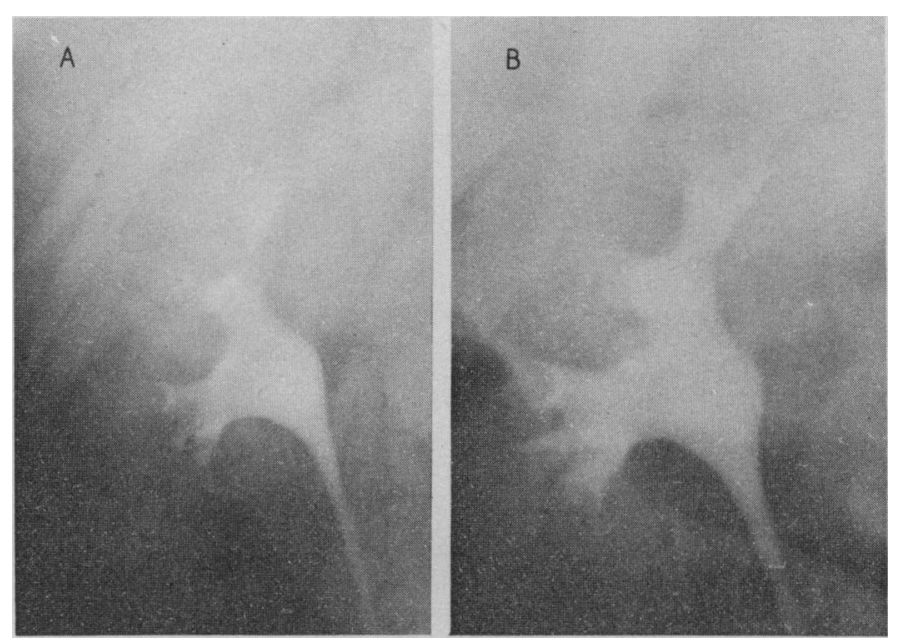

FIG. 1.-Normal I.V.P. A, Five-minute film before compression. B, Same patient-10-minute film with compression. The minor calices are better seen, but retain crisp definition at the fornices. 
FIG. 2.-Overdistensibility on the right side (Case 1).

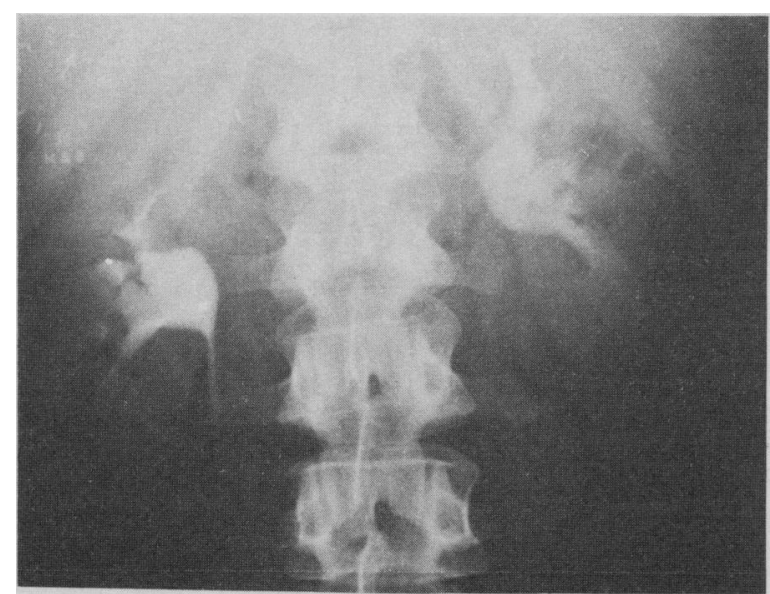

A, Five-minute film before compression. Already a suggestion of overfilling on the right.

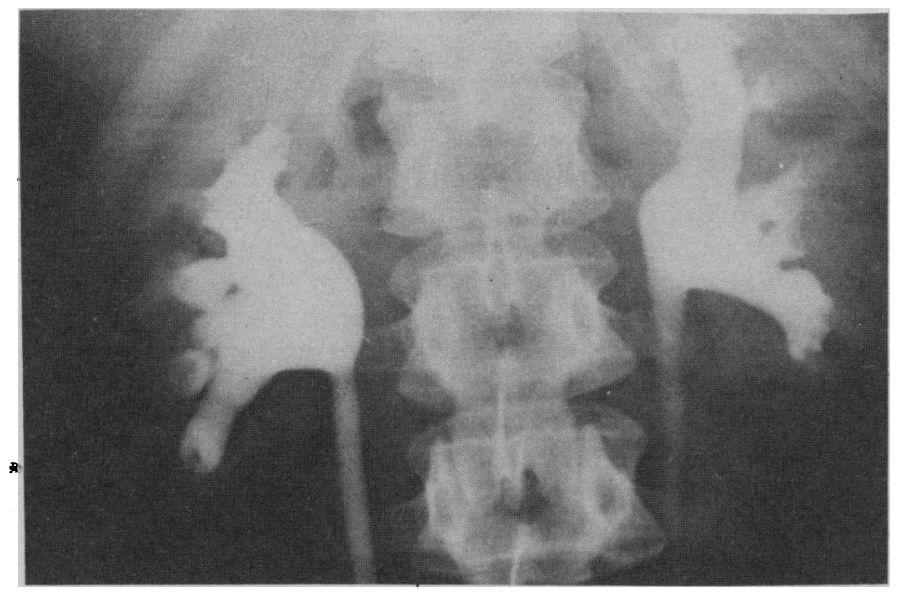

B, Ten-minute film with compression.

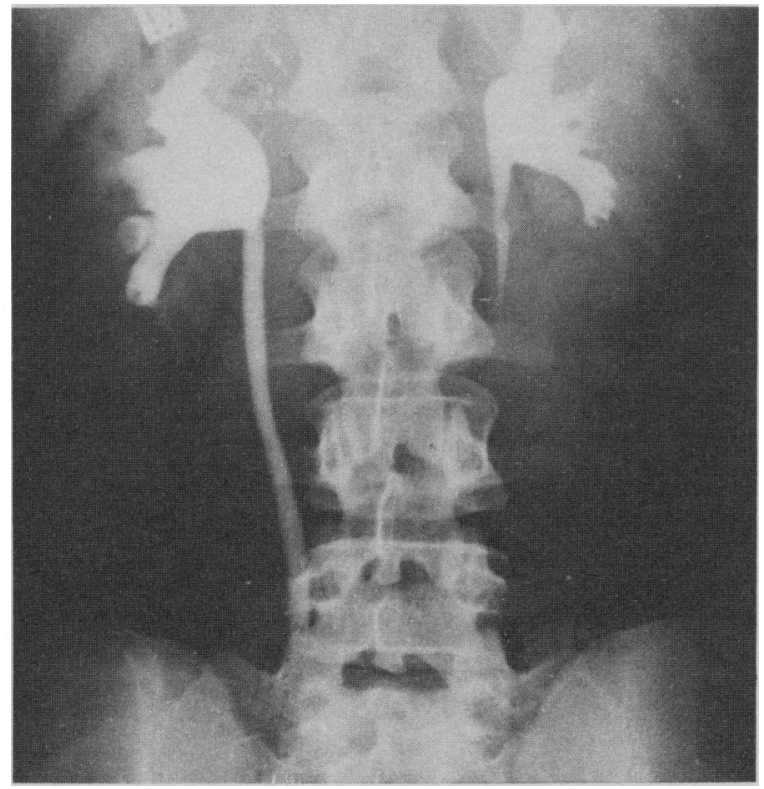

C, Full-length film after release of compression-marked overdistension on the right involving the calices, and the ureter to the pelvic brim.
FIG. 3.-Right overdistensibility (Case 2).

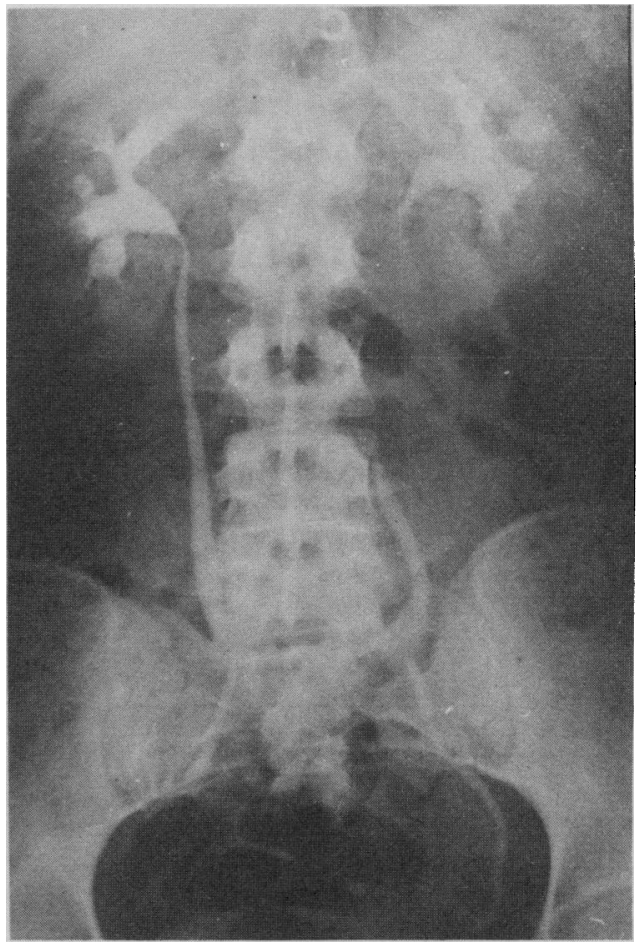

A, Five-minute film-filling of abdominal portion of right ureter.

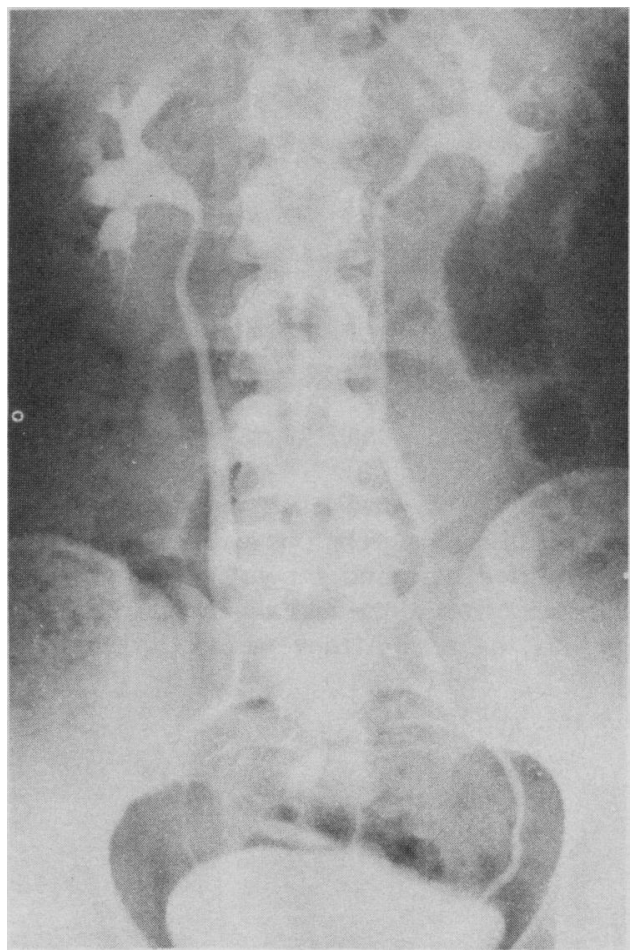

B, After compression, overdistension on the right-left side dubious. 
TABLE 1

\begin{tabular}{|c|c|c|c|c|c|c|c|}
\hline $\begin{array}{l}\text { Case } \\
\text { No. }\end{array}$ & Age & Indication & Type and Duration & $\begin{array}{c}\text { Clinical } \\
\text { Infection }\end{array}$ & M.S.U. & Overdistensibility & $\begin{array}{l}\text { Relation } \\
\text { To "Pill" }\end{array}$ \\
\hline $\begin{array}{ll}1 & \\
2 & : \\
3 & : \\
4 & :\end{array}$ & $\begin{array}{l}23 \\
24 \\
19 \\
20\end{array}$ & $\begin{array}{l}\text { Contraception } \\
\text { Contraception } \\
\text { Contraception } \\
\text { Contraception }\end{array}$ & $\begin{array}{l}\text { Gynovlar, from } 1 / 11 / 68 \\
\text { Volidan, from } 21 / 11 / 68 \\
\text { Demulen, from } 19 / 6 / 69-30 / 10 / 69 \\
\text { Volidan, from August } 1969\end{array}$ & $\begin{array}{l}+ \\
+ \\
+ \\
+\end{array}$ & $\begin{array}{l}\text { Negative } \\
\text { Negative } \\
\text { Negative } \\
\text { Infected }\end{array}$ & $\begin{array}{l}\text { Right calices, both ureters }(23 / 12 / 68) \\
\text { Right calices and ureter }(22 / 10 / 68) \\
\text { Right calices and ureter }(19 / 9 / 69) \\
\text { Bilateral calices }(1 / 12 / 69)\end{array}$ & $\begin{array}{l}\text { On } 2 \text { months } \\
\text { On } 11 \text { months } \\
\text { On } 3 \text { months } \\
\text { On } 4 \text { months }\end{array}$ \\
\hline $\begin{array}{l}5 \\
6\end{array}$ & $\begin{array}{l}20 \\
23\end{array}$ & $\begin{array}{l}\text { Contraception } \\
\text { Period regulation } \\
\text { (Premarital) }\end{array}$ & $\begin{array}{l}\text { Gynovlar, from July } 1968 \\
\text { Gynovlar, from Oct. } 1967-\text { Feb. } 1968\end{array}$ & $\begin{array}{c}+ \\
0 \text { (loin } \\
\text { pain) }\end{array}$ & $\begin{array}{l}\text { Proteus } \\
\text { Negative }\end{array}$ & $\begin{array}{l}\text { Both ureters }(2 / 12 / 68) \\
\text { Right calices }(6 / 11 / 68)\end{array}$ & $\begin{array}{l}\text { Still on } \\
\text { Off } 9 \text { months }\end{array}$ \\
\hline
\end{tabular}

excretion urography are illustrated in Fig. 1. What we consider to be overdistensibility of the calices is shown in Fig. 2, and Fig. 3 illustrates ureteric overdistension. We define overdistensibility to be present when, were it to be seen in a male patient it would be regarded as pathological. The basic change in overdistensibility of the calices is a loss of the sharp cupping of the fornices of the minor calices, an appearance which we consider more than that produced by compression alone. Where the changes have been unilateral, comparison between the normal and abnormal sides has been possible. We diagnose ureteric overdistension if the ureters measure over $8 \mathrm{~mm}$. on at least two films, the measurement being made above the alae of the sacrum. All the clinical details were available to the radiologist who viewed the films, and no attempt has been made to carry out a double-blind study.

\section{Results}

The relevant clinical and radiological data are given in Table I. The six patients were discovered during an investigation into the frequency of upper urinary tract overdistensibility in women (Guyer and Delany, 1970). In that investigation we found a total of 118 women showing overdistensibility of the upper urinary tract; the first 58 of these cases occurred in a consecutive series of 260 female urograms (Table II), and

TABle II.-Factors Associated With Overdistensibility in 260 Consecutive Excretion Urograms in Women

\begin{tabular}{|c|c|c|}
\hline & Total & $\begin{array}{l}\text { No. Showing } \\
\text { Over- } \\
\text { distensibility }\end{array}$ \\
\hline 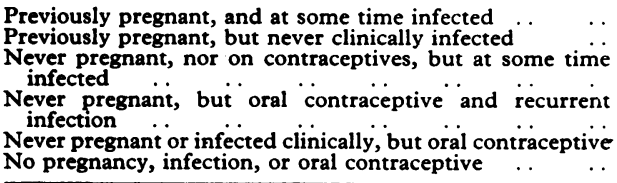 & $\begin{array}{r}140 \\
45 \\
34 \\
6 \\
7 \\
28\end{array}$ & $\begin{array}{l}45 \\
11 \\
- \\
2 \\
-\end{array}$ \\
\hline & 260 & 58 \\
\hline
\end{tabular}

included the first two patients reported here in whom the abnormality appeared to be associated with oral contraceptive therapy. The remaining 60 of the 118 cases have been detected since the consecutive series was completed. Every patient showing overdistensibility had been either pregnant or was taking oral contraceptives, and $74 \%$ of the 118 had also had clinical evidence of urinary tract infection at some stage, though not necessarily in relation to pregnancy. Five of the six patients reported here and showing the changes associated with oral contraceptives alone had also been infected clinically; in fact this was the reason they were referred for excretion urography. All six had received oral contraceptives, though one had ceased to take the drug nine months before the urography was performed. Compared with the abnormalities which may persist after pregnancy, the changes associated with cyclical hormone therapy are not so pronounced.

\section{Discussion}

There is some dispute about the significance of this overdistension. O'Grady and Catell (1966) indicated that dilatation of the urinary collecting system decreases the flow through, the system and gives rise to relative stasis, with defective clearing of the bacteria which multiply there. Hodson (1968) argued similarly. It has been suggested that bacteriuria, once established, is more difficult to eradicate from a dilated system (Leigh et al., 1968; Spiro and Kelsey Fry, 1970). Kass (1962) also claimed that this bacteriuria disposes to toxaemia of pregnancy, premature delivery, and loss of fetal life. This is supported by Kincaid-Smith and Bullen (1965), but disputed by others (Whalley et al., 1965; Leigh et al., 1968).

It may be of significance, therefore, that oral contraceptives produce overdistensibility of the upper urinary tract in some patients, thus promoting bacteriuria and its complications and making clearance of the infection more difficult. While with modern therapy this is unlikely to threaten life, it may play. a significant part in patient morbidity. We are aware of only two other reports on this overdistensibility associated with contraceptive therapy (Byrne, 1966; Marshall et al., 1966), but Byrne does not comment on previous pregnancies, the changes of which are difficult to differentiate. Other authors (Felding, 1966; Corriere et al.; 1968) claim that this overdistensibility does not occur; but the number of patients studied by these authors is small. In an effort to discover the frequency of these changes a further study has been started.

\section{REFERENCES}

Byrne, J. E. (1966). Missouri Medicine, 63, 900

Corriere, J., Murphy, J. J., and Garcia, C.-R. (1968). Surgical Forum, 19, 407. Felding, C. (1966). Acta Obstetricia et Gynecologica Scandinavica, 45, Suppl No. 9,58 .

Guyer, P. B., and Delany, D. (1970). In preparation.

Hodson, C. J. (1968). In Urinary Tract Infection, ed. F. O'Grady and W. Brumfitt, p. 170. London, Oxford University Press.

Kass, E. H. (1962). Annals of Internal Medicine, 56, 46.

Kincaid-Smith, P., and Bullen,.M. (1965). Lancet, 1, 395

Leigh, D. A., Grüneberg, R. N., and Brumfitt, W. (1968). Lancet, 1, 603.

Marshalt, S., Lyon, R. P., and Minkler, D. (1966). Fournal of the"American Medical Association, 198, 782.

O'Grady F., and Catell, W. R. (1966). British fournal of Urology, 38, 149.

Spiro, F. I., and Fry, I. K. (1970). Proceedings of the Royal Society of Medicine, 63,462 .

Whalley, P. J., Martin, F. G., and Peters, P. C. (1965). Gournal of the American Medical Association, 193, 879. 